\title{
Antitussive Efficacy and Safety Profile of Ethyl Acetate Fraction of Terminalia chebula
}

\author{
Rizwan ul Haq, ${ }^{1}$ Abdul Wahab, ${ }^{2}$ Khurshed Ayub, ${ }^{3}$ Khalid Mehmood, ${ }^{1}$ M. Azhar Sherkheli, \\ Rafeeq Alam Khan, ${ }^{4}$ and Mohsin Raza $^{5}$
}

${ }^{1}$ Department of Pharmacy, Hazara University, Havelian Campus, Havelian, Abbottabad 22500, Pakistan

${ }^{2}$ Section of Pharmacology, H.E.J. Research Institute of Chemistry, University of Karachi, Karachi 75270, Pakistan

${ }^{3}$ Comsats Institute of Information Technology, Abbottabad 22000, Pakistan

${ }^{4}$ Department of Pharmacology, Faculty of Pharmacy, University of Karachi, Karachi 75270, Pakistan

${ }^{5}$ Section of Neurosciences and Ethics, Baqiyatallah University of Medical Sciences, Tehran 19945-587, Iran

Correspondence should be addressed to Rizwan ul Haq; rizwanhej@gmail.com

Received 25 May 2013; Accepted 2 July 2013

Academic Editors: K.-A. Chuang and R. Couture

Copyright (c) 2013 Rizwan ul Haq et al. This is an open access article distributed under the Creative Commons Attribution License, which permits unrestricted use, distribution, and reproduction in any medium, provided the original work is properly cited.

\begin{abstract}
Antitussive effects of ethyl acetate fraction of Terminalia chebula on sulphur dioxide $\left(\mathrm{SO}_{2}\right)$ gas induced cough have been examined in mice. Safety profile of Terminalia chebula was established by determining $\mathrm{LD}_{50}$ and acute neurotoxicity. The result showed that extract of Terminalia chebula dose dependently suppressed $\mathrm{SO}_{2}$ gas induced cough in mice. Terminalia chebula, after i.p. administration at dose level $500 \mathrm{mg} / \mathrm{kg}$, offered maximum cough suppressive effects; that is, number of coughs at $60 \mathrm{~min}$ was $12 \pm 1.52$ (mean $\pm \mathrm{SEM}$ ) as compared to codeine $10 \mathrm{mg} / \mathrm{kg}$; i.p., dextromethorphan $10 \mathrm{mg} / \mathrm{kg}$; i.p., and saline, having frequency of cough $10.375 \pm 0.866,12.428 \pm 0.81$, and $46 \pm 2.61$, respectively. $\mathrm{LD}_{50}$ value of Terminalia chebula was approximately $1265 \mathrm{mg} / \mathrm{kg}$, respectively. No sign of neural impairment was observed at antitussive doses of extract. Antitussive effect of Terminalia chebula was partly reversed with treatment by naloxone $(3 \mathrm{mg} / \mathrm{kg}$; s.c.) while rimcazole $(3 \mathrm{mg} / \mathrm{kg} ; \mathrm{s.c}$.) did not antagonize its cough suppression activity. This may suggest that opioid receptors partially contribute in antitussive action of Terminalia chebula. Along with this, the possibility of presence of single or multiple mechanisms activated by several different pharmacological actions (mainly anti-inflammatory, antioxidant, spasmolytic, antibacterial, and antiphlegmatic) could not be eliminated.
\end{abstract}

\section{Introduction}

Plants have formed the basis of sophisticated traditional medicine systems that have been in existence for thousands of years [1]. Ayurvedic, Unani, Kampo, and traditional Chinese medicine based systems continue to play an essential role in primary health care [2]. It has been estimated by World Health Organization (WHO) that approximately $80 \%$ of world's inhabitants, mainly residing in developing countries, rely on traditional medicine, and $85 \%$ of traditional medicine involves the use of plant extracts or their active principles. The plant-derived products also play a significant role in health care system of the remaining $20 \%$ population, mainly residing in developed countries. In the USA, for example, 25\% of all prescriptions dispensed from community pharmacies from 1959 to 1980 contained plant extracts or active principles prepared from higher plants [3].

Most popular cough medicines throughout the world are based on herbal derivatives. The number of plants that have been accepted as antitussives by different societies is immense. For example, the USA Physician Desk Reference (PDR) for Herbal Medicine categorizes over 100 herbs as antitussives [4]. Opium, Ammi, coltsfoot, plantain ma huang, thyme, and so forth are used from centuries in folklore to treat coughs and other pulmonary ailments. Frequent reports have been published in the botanical and ethnopharmacological literature suggesting that traditional antitussive plants from Europe, Asia, Africa, and elsewhere may offer significant cough suppressive effects (e.g., see [5-7]). Numerous compounds such as codeine, morphine, 
noscapine, bromhexine, guaifenesin, ephedrine, cromolyn, and their derivatives, isolated from different plant species, are well-established western medicines for treating cough or underlying pathologies [8].

Terminalia chebula Retz. (family Combretaceae), locally called "Harh" or "Harir" in Urdu and Punjabi, is a tree native to subcontinent [9]. Fruits of Terminalia chebula are considered in ayurvedic and unani medicine as stomachic, tonic, carminative, expectorant, anthelmintics, antidysenteric, alternative, and antispasmodic $[9,10]$. These are useful in asthma, bronchosis, cough, sore throat, thirst, vomiting, inflammation, tumor, bleeding piles, pains, chronic and recurrent fever, diarrhea, diabetes, dysentery, anemia, and eye diseases. Fruits, coarsely powdered and smoked in pipe, afford relief in fit of asthma [10]. Terminalia chebula in compound preparations offers remarkable cure for relief of phlegmatic conditions [11].

Cough can be induced in experimental animals by chemical, mechanical, or electrical stimulation of sensory nerve afferents in the larynx, trachea, or bronchial mucosa or by stimulation of CNS. However, it is considered that cough obtained by chemical stimulation is more comparable to that in humans than is obtained with other tussigenic stimuli [12]. Sulphur dioxide gas has been used to elicit cough in various experimental animals, for example, in cats [13], in rats [14], in mice [5], and so forth. In present studies, sulphur dioxide gas induced murine cough models, developed by Miyagoshi and colleagues in 1986 [5] were used to investigate antitussive efficacy of testing materials (see also $[6,7]$ ).

\section{Material and Method}

2.1. Plant Material and Extraction. The dried fruits of Terminalia chebula were purchased from local herbal market in Karachi, Pakistan, and identified by taxonomist at the Department of Botany, University of Karachi, Pakistan. A voucher specimen has been deposited in the herbarium of Department of Botany, University of Karachi, Pakistan, for future references. The dried fruits were crushed and were soaked in ethanol for 3-4 days, and ethanol was decanted and evaporated to obtain ethanolic extract. Remaining fruit material was again extracted with ethanol in the same manner. Both extracts were mixed and then partitioned between hexane, chloroform, ethyl acetate, butanol, and water. Ethyl acetate fraction was subjected to antitussive evaluation.

2.2. Experimental Animals. Studies were carried out on NMRI (Naval Medical Research Institute, USA) mice weighing 20-30 g, obtained from the animal house facility of Section of Pharmacology, H.E.J. Research Institute of Chemical Sciences, University of Karachi. Animals of either sex were used. Animals were kept in groups of 5-6 in transparent plastic cages and provided standard $12 \mathrm{hrs} \mathrm{light/dark}$ cycle beginning at 8 a.m. Standard food and water were available ad libitum. With some exception, all experiments were carried out between 8 a.m. and 6 p.m. All efforts were made to minimize animals suffering and to reduce the number of animals used.

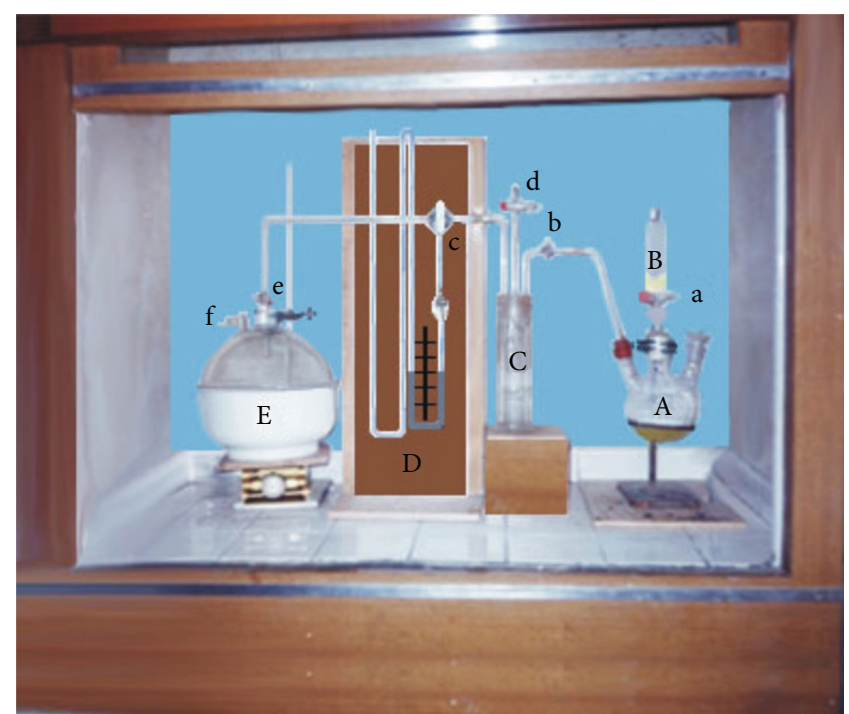

FIgURE 1: Apparatus used in sulphur dioxide gas induced cough model. A: three-necked round bottom flask, containing 39\% $\mathrm{NaHSO}_{3}$ solution, B: dropping funnel having concentrated $\mathrm{H}_{2} \mathrm{SO}_{4}$, $\mathrm{C}$ : gas reservoir, $\mathrm{D}$ : water manometer, and $\mathrm{E}$ : desiccator. The procedure used to produce sulphur dioxide gas is described in text.

2.3. Chemicals. Sulphuric acid and polyethylene glycol (PEG) 400 were purchased from Sigma Chemical Company, St. Louis, MO, USA. Sodium hydrogen sulphite was purchased from Merck, Darmstadt, Germany. Codeine phosphate, dextromethorphan hydrobromide, and naloxone hydrochloride were received as gifts from Wilson Pharmaceutical Co., Islamabad, Pakistan; Abbott Laboratories (Pakistan) Limited, Karachi, Pakistan, and Haji Medicine Co., Rawalpindi, Pakistan, respectively. Rimcazole dihydrochloride was received as a gift from John Church, Department of Anatomy and Cell Biology, Faculty of Medicine, The University of British Columbia, Vancouver, Canada, and Jonathan Katz, Psychobiology Section, NIDA Intramural Research Program, National Institute of Health, Baltimore, USA.

Testing material was dissolved in PEG 400. PEG 400 was diluted in water at a ratio of $30: 70$. All the chemicals were dissolved in normal saline. All the solutions were freshly made at the day of testing and administered to a final volume of $0.1 \mathrm{~mL} / 10 \mathrm{~g}$ body weight of mice. Testing material and all chemicals were administered intraperitoneally (i.p.), with exception of naloxone and rimcazole, which were administered subcutaneously (s.c.). All doses (of testing material and chemicals) were expressed in $\mathrm{mg} / \mathrm{kg}$ of body weight of animals, excluding the weight of their salts.

2.4. Antitussive Evaluation. Antitussive identification and quantification of testing material were determined by sulphur dioxide $\left(\mathrm{SO}_{2}\right)$ gas induced murine cough model described by Miyagoshi and colleagues in 1986 [5]. The experimental model is shown in Figure 1, where " $\mathrm{A}$ " is a $500 \mathrm{~mL}$ threenecked round bottom flask containing aqueous saturated (39\%) sodium hydrogen sulphite solution. By opening the stopcock "a" of dropping funnel "B," concentrated sulphuric 
acid (98\%) was introduced to generate $\mathrm{SO}_{2}$ gas. $\mathrm{SO}_{2}$ gas filled previously in "A" and by opening stopcocks "b" and "c" pressure in gas reservoir " $\mathrm{C}$ " was elevated, which was recorded by the water manometer "D." The stopcock "b" was then closed and stopcock "d" was opened slightly until the pressure in " $\mathrm{D}$ " reached $6 \mathrm{mmHg}$ (constant throughout the experiment), then stopcock "d" was closed. These procedures were conducted in a draught. Cough response of an animal was observed by placing the animal in desiccator "E." Stopcocks "c," "e," and "f" were opened, respectively, and when the pressure in "D" became 0 (zero) $\mathrm{mmHg}$, all the stopcocks were closed immediately. A certain amount of $\mathrm{SO}_{2}$ (which was fixed throughout the experiment) was introduced into the desiccator in this way. One minute after introduction of gas, the animal was taken out of the desiccator, and number of coughs produced during the initial $5 \mathrm{~min}$ of exposure was counted by an up-ended filter funnel, with a stethoscope at the tip in which the mouse was confined.

Animals were divided into seven groups, containing 8 mice each. One served as control group (saline, $0.1 \mathrm{~mL} / 10 \mathrm{~g}$; i.p.), three groups for ethyl acetate fraction of Terminalia chebula EAFTc $(125,250$, and $500 \mathrm{mg} / \mathrm{kg}$; i.p.), two groups for standard drugs codeine phosphate $(10 \mathrm{mg} / \mathrm{kg}$; i.p.) and dextromethorphan $(10 \mathrm{mg} / \mathrm{kg}$; i.p.), and the remaining group was used for vehicle (PEG 400, $0.1 \mathrm{~mL} / 10 \mathrm{~g}$; i.p.). These doses of testing material were selected on the basis of toxicity profile and preliminary antitussive screening (data not shown). Initially, the number of coughs for each animal was determined at $0 \mathrm{~min}$, before administration of any chemical or testing material. Hence, it has been illustrated that cough response to a given stimulus varies from animal to animal but that repeated assessments within the same animals are fairly reproducible [15]. Thus, animals having low or high cough threshold were not entertained for further studies. Number of coughs was observed for all animal groups at 30,60, and $90 \mathrm{~min}$ (after drug administration) intervals by using same procedure. The time interval at which the greatest antitussive action was observed was taken as time of the peak effect.

2.5. $L D_{50}$. The dose of testing material that caused death in $50 \%$ of the animals within $24 \mathrm{hrs}\left(\mathrm{LD}_{50}\right)$ was calculated using the method described by Lorke in 1983 [16]. Briefly, EAFTc at the doses of 10,100 , and $1000 \mathrm{mg} / \mathrm{kg}$ was administered i.p. to groups of three mice each. Upon the results of mortality in each group after $24 \mathrm{hrs}, 4$ more mice were administered different doses of EAFTc in order to obtain the least and most toxic value, and $\mathrm{LD}_{50}$ was calculated by geometric mean of these values.

2.6. Acute Neurotoxicity. The potential of EAFTc to induce neural impairment was determined by inverted screen acute neurotoxicity test developed by Coughenour and colleagues in 1977 [17]. The apparatus consists of six $12.6 \mathrm{~cm}$ square platforms of $0.6 \mathrm{~cm}$ wire mesh supported by metal bars that in turn are mounted on a metal rod. Mice were pretested on the apparatus the day preceding the experiment, and those failing the task were not used for the subsequent drug test. For the test procedure, mice were dosed with incremental doses of
$\operatorname{EAFTc}(125,250,500$, and $1000 \mathrm{mg} / \mathrm{kg}$; i.p.), placed 30, 60 and, $120 \mathrm{~min}$ on individual platforms and rod-rotated through an $\operatorname{arc}$ of $180^{\circ}$. Mice unable to climb to an upright position for $1 \mathrm{~min}$ duration were rated as failures [17]. Eight mice were used for each dose.

2.7. Elucidation of Mechanism of Action. To determine the possible mechanism of antitussive effects of Terminalia chebula, we used a nonselective opioid receptors antagonist naloxone to antagonize the cough suppressive activity of EAFTc at different doses. In detail, effects of naloxone $(3 \mathrm{mg} / \mathrm{kg}$, s.c.; $10 \mathrm{~min}$ pretreatment) were examined against the antitussive activities of saline $(0.1 \mathrm{~mL} / 10 \mathrm{~g}$, i.p.; $30 \mathrm{~min}$ pretreatment), opioid receptor agonist, codeine $(10 \mathrm{mg} / \mathrm{kg}$, i.p.; 30 min pretreatment), sigma $(\sigma)$ receptor agonist, dextromethorphan $(10 \mathrm{mg} / \mathrm{kg}$, i.p.; $30 \mathrm{~min}$ pretreatment), and EAFTc (250 and $500 \mathrm{mg} / \mathrm{kg}$, i.p.; 1-hour pretreatment) [18, 19]. Pretreatment times and doses were selected for each compound based on experiment conducted in this study and published reports $[18,19]$. The effects of naloxone on frequency of coughs were also determined by s.c. administration of different doses of naloxone, and results were compared with normal saline. In another set of experiments, we also tested the effects of sigma receptors antagonist rimcazole against antitussive effects of different doses of EAFTc. Briefly, effects of rimcazole $(3 \mathrm{mg} / \mathrm{kg}$, s.c.; $45 \mathrm{~min}$ pretreatment) were determined against saline $(0.1 \mathrm{~mL} / 10 \mathrm{~g}$, i.p.; $30 \mathrm{~min}$ pretreatment), codeine (10 mg/kg, i.p.; $30 \mathrm{~min}$ pretreatment), dextromethorphan (10 $\mathrm{mg} / \mathrm{kg}$, i.p.; $30 \mathrm{~min}$ pretreatment), and EAFTc (250 and $500 \mathrm{mg} / \mathrm{kg}$, i.p.; 1-hour pretreatment) [18, 19]. The effects of rimcazole on frequency of coughs were also determined by s.c. administration of different doses of rimcazole, and results were compared with normal saline.

2.8. Statistics. Data were analyzed using statistical analyzing software "Microcal Origin version 6." The number of coughs was expressed as mean values \pm SEM. Student's $t$-test was performed for each experiment to determine the difference between control and experimental groups. Difference was considered significant if $P$ values were less than 0.05 .

\section{Results}

3.1. Antitussive Efficacy. Intraperitoneally (i.p.) administered codeine $(10 \mathrm{mg} / \mathrm{kg})$ inhibited $\mathrm{SO}_{2}$ gas induced coughing in mice (Figure 2). Codeine reduced frequency of cough from $47.125 \pm 2.21$ to $10.375 \pm 0.56(P<0.001)$, that is, $77.98 \%$ inhibition in incidence of coughing at $60 \mathrm{~min}$ interval after drug administration. Dextromethorphan (10 mg/kg; i.p.) dose-dependently inhibited cough produced by $\mathrm{SO}_{2}$ gas in mice (Figure 2). At $10 \mathrm{mg} / \mathrm{kg}$ cough was inhibited by $73.55 \%$ at $60 \mathrm{~min}$ after drug administration $(P<0.001)$. As illustrated in Figure 2, the inhibitory effects of codeine $(10 \mathrm{mg} / \mathrm{kg}$; i.p.) and dextromethorphan $(10 \mathrm{mg} / \mathrm{kg}$; i.p.) were maintained for at least $90 \min (P<0.001)$.

i.p. administration of EAFTc significantly decreased number of coughs induced by $\mathrm{SO}_{2}$ gas in a dose-dependent manner $(P<0.01 ; P<0.001)$. As shown in Figure 2, 

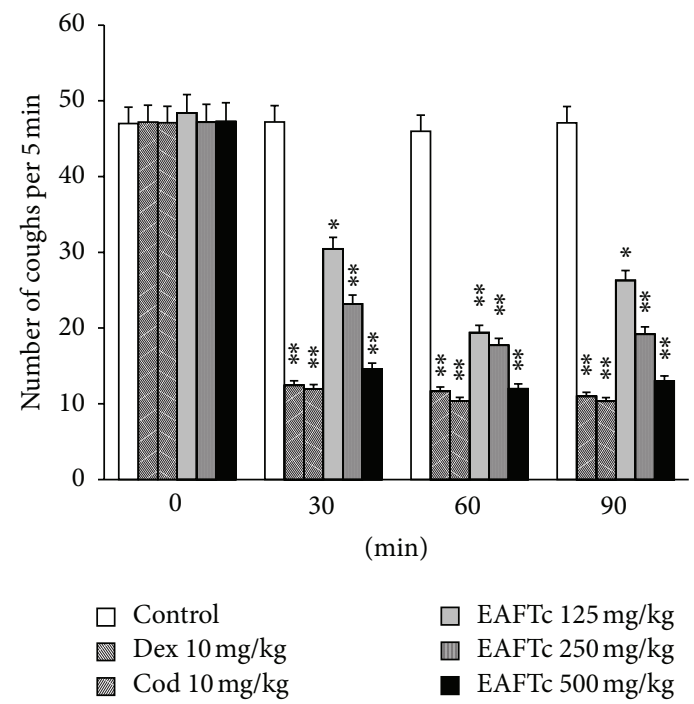

FIGURE 2: Effect of EAFTc (ethyl acetate fraction of Terminalia chebula $)(125,250$, and $500 \mathrm{mg} / \mathrm{kg})$ on sulphur dioxide gas induced cough by i.p. administration at different time intervals. Number of coughs were counted 5 minutes after cough challenge and expressed as mean \pm SEM, obtained in 8 mice in each group. Significant differences from saline control were indicated as ${ }^{*} P<0.01$ and ${ }^{* *} P<0.001$ by Student's $t$-test.

EAFTc (125 and $250 \mathrm{mg} / \mathrm{kg}$ ) exhibited maximum inhibition of coughing at $60 \mathrm{~min}$, and then there was a slight decrease in antitussive action of EAFTc after $60 \mathrm{~min}$. However, EAFTc $500 \mathrm{mg} / \mathrm{kg}$ produced long duration of action after i.p. administration with TPE $60 \mathrm{~min}$, and cough inhibition was maintained up to at least $90 \mathrm{~min}$. The maximum inhibition of cough produced by the extract was at $500 \mathrm{mg} / \mathrm{kg}$ dose level; incidence of coughs was decreased from $47.28 \pm 1.79$ (mean \pm SEM) to $12 \pm 1.52$ (mean \pm SEM) at $60 \mathrm{~min}$ after drug administration, whereas codeine $(10 \mathrm{mg} / \mathrm{kg}$; i.p.) exhibited a decrease in number of coughs from $46 \pm 2.61$ to $10.375 \pm$ 0.565 (mean \pm SEM) at the same time interval. These observations reveal that EAFTc $(500 \mathrm{mg} / \mathrm{kg}$; i.p.) was as active as codeine $(10 \mathrm{mg} / \mathrm{kg}$; i.p.) and dextromethorphan $(10 \mathrm{mg} / \mathrm{kg}$; i.p.). PEG $400(10 \mathrm{~mL} / \mathrm{kg}$; i.p.) alone was without influence on the incidence of coughs in the given time frame after $\mathrm{SO}_{2}$ gas challenge; the incidence of coughs was $47.125 \pm 1.301$, $46.875 \pm 1.563,45.75 \pm 1.578$, and $46.875 \pm 1.44$ at $0 \mathrm{~min}$ (before PEG administration) and 30,60, and $90 \mathrm{~min}$ after PEG administration, respectively. So it is clear that the vehicle (PEG) does not integrate in cough inhibition provoked by EAFTc.

\subsection{Toxicity Profile}

3.2.1. $L D_{50}$. The $\mathrm{LD}_{50}$ of ethyl acetate fraction of Terminalia chebula after i.p. dosing was calculated to be $1264.91 \mathrm{mg} / \mathrm{kg}$ per $24 \mathrm{hrs}$. Extract produced purgative effect in most of animals before death.

3.2.2. Acute Neurotoxicity. The effects of EAFTc on neural impairment and motor function were determined by inverted

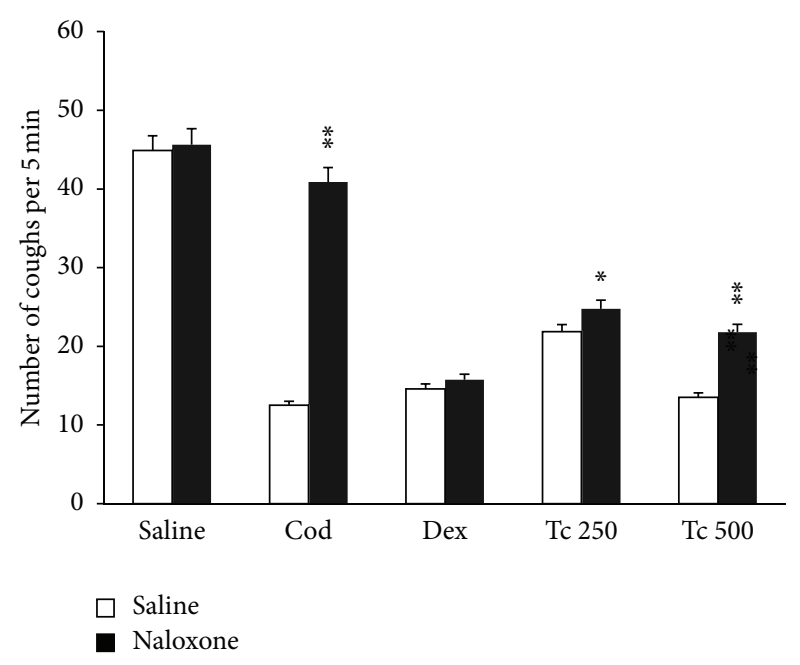

Figure 3: Effects of naloxone $(3 \mathrm{mg} / \mathrm{kg}$ ) on the antitussive effects of cod (codeine $10 \mathrm{mg} / \mathrm{kg}$ ), dex (dextromethorphan $10 \mathrm{mg} / \mathrm{kg}$ ), and Tc 250 (ethyl acetate fraction of Terminalia chebula $250 \mathrm{mg}$ ) and Tc 500 (ethyl acetate fraction of Terminalia chebula $500 \mathrm{mg}$ ). Naloxone was injected s.c. $10 \mathrm{~min}$ before cough challenge. Codeine and dextromethorphan were injected i.p. 30 min while testing materials were administered i.p. 60 min before cough challenge in mice. Each column represents mean with SEM for at least 8 mice. Significant differences from saline control were indicated as ${ }^{*} P<0.05$ and ${ }^{* *} P<0.01$ by Student's $t$-test.

screen acute neurotoxicity test [17]. EAFTc was observed at different doses $(125,250,500$, and $1000 \mathrm{mg} / \mathrm{kg}$; i.p.) and time intervals $(30,60,90$, and $120 \mathrm{~min})$ in mice. Terminalia chebula did not express any noticeable sign of acute neurotoxicity at any specified time when tested up to $1000 \mathrm{mg} / \mathrm{kg}$.

\subsection{Effect of Naloxone on Antitussive Activity of Terminalia} chebula. A nonselective opioid receptor antagonist naloxone (up to $4 \mathrm{mg} / \mathrm{kg}$ after s.c. administration) alone was without any significant influence on the incidence of cough after $\mathrm{SO}_{2}$ gas challenge, representing mean values of cough efforts $44.88 \pm 1.46,44 \pm 1.21$, and $45.62 \pm 1.39$ (mean \pm SEM) at $30 \mathrm{~min}$ after s.c. dosing of $1 \mathrm{mg} / \mathrm{kg}, 2 \mathrm{mg} / \mathrm{kg}$, and $4 \mathrm{mg} / \mathrm{kg}$ of naloxone, respectively. Mice treated with codeine $(10 \mathrm{mg} / \mathrm{kg}$; i.p.) coughed an average of $12.5 \pm 0.867$ times (Figure 3), which represented $72.82 \%$ inhibition of the cough reflex. In the group of codeine-treated animals that received naloxone (3 mg/kg; s.c.), the incidence of cough was $40.875 \pm 1.60(P<$ 0.01 ), demonstrating an attenuation of the antitussive effect of codeine by naloxone (Figure 3 ). Naloxone ( $3 \mathrm{mg} / \mathrm{kg}$; s.c.) did not antagonize inhibitory effects of dextromethorphan (Figure 3). Naloxone partially antagonized the inhibitory responses produced by intraperitoneally administered EAFTc $(250$ and $500 \mathrm{mg} / \mathrm{kg})$, as illustrated in Figure $3(P<0.05$ and $P<0.01$, resp.).

3.4. Effect of Rimcazole on Antitussive Activity of Terminalia chebula. The $\sigma$-receptor antagonist rimcazole (up to $10 \mathrm{mg} / \mathrm{kg}$; s.c.) alone had no effect on $\mathrm{SO}_{2}$ gas induced cough 


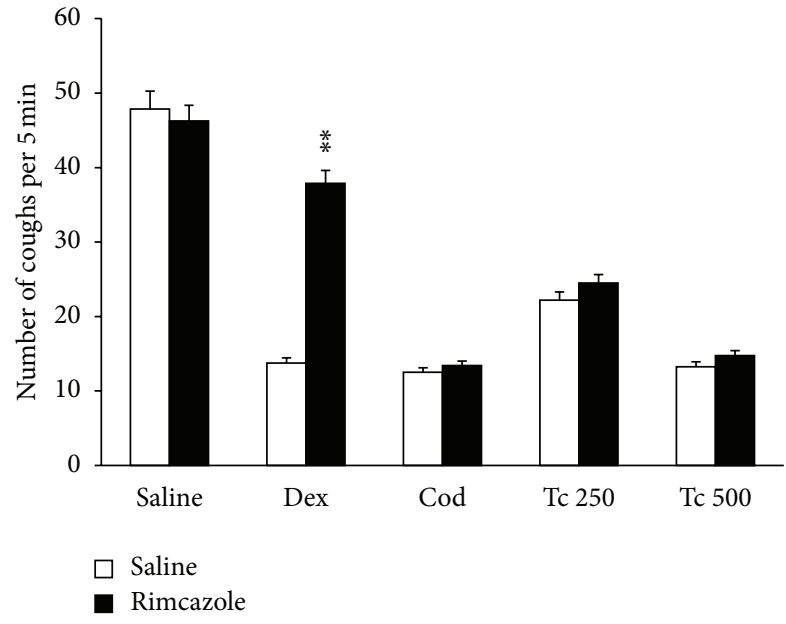

FIGURE 4: Effect of rimcazole $(3 \mathrm{mg} / \mathrm{kg} ; \mathrm{s.c})$ on the antitussive effects of dex (dextromethorphan $10 \mathrm{mg} / \mathrm{kg}$; i.p.), codeine $(10 \mathrm{mg} / \mathrm{kg}$; i.p.), and Tc (ethyl acetate fraction of Terminalia chebula 250 and $500 \mathrm{mg} / \mathrm{kg}$; i.p.). Rimcazole was administered $45 \mathrm{~min}$ before cough challenge. Codeine and dextromethorphan were administered $30 \mathrm{~min}$ before cough induction, and testing material was administered 60 min before cough induction in mice. Each column represents mean with SEM for at least 8 mice. Significant differences from saline control were indicated as ${ }^{*} P<0.05$ and ${ }^{* *} P<0.01$ by Student's $t$-test.

in mice, showing mean values of cough efforts $47.375 \pm 1.32$, $46.25 \pm 1.82$, and $45.25 \pm 1.62$ (mean \pm SEM) at $30 \mathrm{~min}$ after s.c. dosing of $3 \mathrm{mg} / \mathrm{kg}, 6 \mathrm{mg} / \mathrm{kg}$, and $10 \mathrm{mg} / \mathrm{kg}$ rimcazole, respectively. The $\sigma$-receptor agonist dextromethorphan $\left(10 \mathrm{mg} / \mathrm{kg}\right.$; i.p.) inhibited $\mathrm{SO}_{2}$ gas induced coughs in mice. As illustrated in Figure 4, the antitussive activity of dextromethorphan $(10 \mathrm{mg} / \mathrm{kg}$; i.p.) was significantly inhibited by rimcazole $(3 \mathrm{mg} / \mathrm{kg}$; s.c.): cough incidence $=13.75 \pm 0.881$ coughs in dextromethorphan-treated animals versus $37.875 \pm$ 1.652 coughs in the animals treated with rimcazole and dextromethorphan $(P<0.05)$. In contrast, rimcazole did not influence the antitussive activity of codeine $(10 \mathrm{mg} / \mathrm{kg}$; i.p.) and EAFTc (250 and $500 \mathrm{mg} / \mathrm{kg}$; i.p.), as shown in Figure 4 $(P>0.05)$.

\section{Discussion}

Cough is the most common respiratory symptom that has been experienced by every human. It is an essential protective and defensive act whose action secures the removal of mucus, noxious substances, and infections from the larynx, trachea, and larger bronchi. On the other hand, a number of patients have nonproductive cough, which is not associated with mucus clearance and may have a different stimulation. It may be the first overt sign of disease of airways or lungs and may significantly contribute to the spread of airborne infections and, in some instances, may result in severe functional and structural damage to the organism. The primary action of currently available cough suppressants (opiates, dextromethorphan, etc.) is on the central cough pathway. The significant side effects of these agents such as constipation, respiratory depression, dependence, drowsiness, and death from this action limit their use in human [20]. There is a current huge unmet need for the development of safe, effective antitussive therapeutic options in the treatment of persistent cough as alternative to existing medications.

Safety is one of the major concerns in the development of new treatment for cough. Opiates with excellent cough suppressant activity offer some relief to patients with cost of numerous severe and life-complicating side effects such as the attenuation of respiratory centre activity, decrease of secretion, increase of sputum viscosity, decrease in expectoration, dependence, bronchoconstriction, and constipation [21]. Most of these adverse effects are produced as a result of their centrally mediated actions at brainstem level. Thus testing material should offer antitussive activity with minimum neurotoxicity, and antitussive doses should be lower than doses responsible for impaired motor function, characterized by ataxia, sedation, altered motor activity, and impaired righting reflex. Inverted screen acute neurotoxicity test was used to quantify the effect of testing material on motor function. In this test, compounds with sedative and/or ataxic properties produce dose-dependent increase in screen test failures, whereas other classes of drugs (e.g., psychomotor stimulants) do not. Terminalia chebula did not elicit motor impairment and ataxia when tested up to $1000 \mathrm{mg} / \mathrm{kg}$. The result of acute toxicity tests indicated that after i.p. dosing EAFTc possessed a more favorable acute safety profile when compared to findings by others for currently used compounds, namely, codeine and dextromethorphan. These observations illustrate that this extract possesses wide therapeutic range.

Terminalia chebula seems to have a quite good ability to inhibit chemically induced cough. The ability of Terminalia chebula in various doses to suppress coughing was compared to commonly used drugs in clinical practice. The excellent cough suppression activity of codeine, a narcotic antitussive, is accompanied with serious side effects, which could limit its use [21]. Testing material was compared with another antitussive, dextromethorphan, which has fewer unwanted effects. The tested substance, Terminalia chebula, at dose level $125 \mathrm{mg} / \mathrm{kg}$ has slightly lower activity than codeine $10 \mathrm{mg} / \mathrm{kg}$ and dextromethorphan $10 \mathrm{mg} / \mathrm{kg}$. However, at higher doses $(500 \mathrm{mg} / \mathrm{kg})$, it has antitussive activity similar to codeine $(10 \mathrm{mg} / \mathrm{kg})$ and dextromethorphan $(10 \mathrm{mg} / \mathrm{kg})$. These results provide pharmacological evidence in support of folklore claims as an antitussive agent.

To determine whether the antitussive activity of EAFTc was attributed via activation of opioid receptors, it was tested in presence of naloxone, a nonselective opioid receptor antagonist. Codeine was used as a standard opioid receptor agonist whose antitussive activity has been shown previously to be inhibited by naloxone [22]. The antitussive activity of EAFTc at lower dose level $(250 \mathrm{mg} / \mathrm{kg})$ was slightly reversed with treatment by naloxone. However, cough suppressant activity of EAFTc at higher doses was more significantly reduced by naloxone. It seems plausible to assume that higher doses of EAFTc were required to induce opioid-mediated inhibition of sulphur dioxide gas provoked cough in mice. This data provides evidence that antitussive activity of EAFTc at low doses was not mainly mediated by opioid receptors 
but increasing activity of EAFTc at higher doses could be explained as a result of opioid receptor-mediated inhibition.

Dextromethorphan is a commonly used nonnarcotic antitussive, which has a greater affinity for sigma receptor [23]. In this study, reduction in antitussive action of dextromethorphan by treatment with rimcazole was confirmed [18]. Rimcazole, at the dose which significantly inhibited the antitussive activity of dextromethorphan, did not affect the antitussive activity of EAFTc. This finding suggests that antitussive effect of EAFTc in this model is independent of activity at the sigma receptor.

It is more likely to suggest that EAFTc may exert antitussive action via multiple mechanisms, both centrally and peripherally. Plant extracts exhibit multiplicity of mechanism, which is activated by several different types of chemical compounds [24]. Apart from opioid and sigma receptor agonists, recent understandings of pharmacology and physiology of cough have introduced several centrally located targets (GABA-B receptor agonists, tachykinin receptor antagonists, and nociceptin), which play a leading role in modulating cough reflex [25-27]. The possible involvement of any one or more of these in antitussive activity of EAFTc could not be excluded.

EAFTc may possess peripheral antitussive activity via suppressing one or more components of peripheral limb of cough reflex. Phytochemicals have great ability to mask airways nerve endings (irritant receptors) due to their mucilaginous properties $[28,29]$. The anti-inflammatory and antiallergic potential of Terminalia chebula [30] could be another factor accountable for its peripheral mechanism. Existence of opioid receptors in periphery is well recognized [22, 31]. It seems more logical that opioid-mediated cough suppression may be achieved from periphery rather than centrally. Hence, pharmacokinetic profile of EAFTc is a matter of great concern, and that will decide whether EAFTc enters CNS or does not.

An increase in exogenous or endogenous oxidative stress can protease-antiprotease imbalance within the alveolar structures to the development of chronic inflammation [32] and emphysema [33]. This established role of oxidants in lung tissue injury and disease has promoted the hypothesis that antioxidants may act as preventive agents. Several reports conclude that a high concentration of antioxidants like ascorbic acid and alpha tocopherol could be one of the factors inhibiting chronic cough $[34,35]$. The extract of fruits of Terminalia chebula possesses potent antioxidant activity [3638]. Furthermore, the influence of airway muscle contractility may be another factor influencing cough, as Terminalia chebula possesses antispasmodic activity [30, 39, 40].

Multiplicity of constituents present in the extract may yield massive interactions. Some components may enhance the intensity of activity of active agent at opioid receptor by exerting synergistic effects. Still others may lessen the opioidmediated antitussive efficacy of extract. The possibility of presence of more than one active principle with different site of actions could not be eliminated. Further fractionalization of the extract of Terminalia chebula may enhance the possibility of getting active principle(s)/fraction(s) with more precise mechanism.
It is supposed that several pharmacological properties (mainly anti-inflammatory, antioxidant, spasmolytic, antibacterial, and antiphlegmatic) may contribute in antitussive efficacy of Terminalia chebula. These pharmacological properties of extract of Terminalia chebula may validate the popular use of this herb in cough related to numerous respiratory diseases.

\section{Conclusion}

The present study indicates that extract of Terminalia chebula possesses antitussive activity against sulphur dioxide gas evoked cough in mice. This activity of the plant was partly reversed by naloxone, but it was not affected with treatment by rimcazole, indicating a partial involvement of opioid receptors in inhibition of coughing. In addition, the antitussive potential of this plant correlates with various pharmacological properties, which may justify its widespread use in various respiratory conditions in traditional medicine. Further studies aimed at isolation of the active compounds responsible for antitussive activity are ongoing in our laboratory.

\section{Acknowledgments}

This work was accomplished by an institutional grant from the Department of Pharmacology, University of Karachi, Pakistan, and an amazing support from Dr. John Church and Dr. Jonathan Katz.

\section{References}

[1] P. H. Abelson, "Medicine from plants," Science, vol. 247, article 513 , no. 4942, 1990.

[2] H. G. Vogel, "Similarities between various systems of traditional medicine. Considerations for the future of ethnopharmacology," Journal of Ethnopharmacology, vol. 35, no. 2, pp. 179-190, 1991.

[3] N. R. Farnsworth, O. Akerele, and A. S. Bingel, "Medicinal plants in therapy," Bulletin of the World Health Organization, vol. 63, no. 6, pp. 965-981, 1985.

[4] J. Gruenwald, T. Brendler, and C. Jaenicke, Eds., PDR for Herbal Medicine, Medical Economics Company, Montvale, NJ, USA, 2nd edition, 2001.

[5] M. Miyagoshi, S. Amagaya, and Y. Ogihara, "Antitussive effects of L-ephedrine, amygdalin, and Makyokansekito (Chinese traditional medicine) using a cough model induced by sulfur dioxide gas in mice," Planta Medica, vol. 4, pp. 275-278, 1986.

[6] R.-U. Haq, A.-U. A. Shah, A.-U. Khan et al., "Antitussive and toxicological evaluation of Vitex negundo," Natural Product Research, vol. 26, no. 5, pp. 484-488, 2012.

[7] R. U. Haq, U. Farooq, A. Wahab, M. Raza, V. U. Ahmad, and R. A. Khan, "Investigation of antitussive and toxicological activity of Ballota limbata in mice," Pharmaceutical Biology, vol. 49, no. 6, pp. 627-632, 2011.

[8] R. W. März and H. Matthys, "Phytomedicines in the treatment of diseases of the lower respiratory tract. What is proven?" in Phytopharmaka III, D. Loew and N. Reitbrock, Eds., pp. 161-178, Steinkopff, Darmstadt, Germany, 1997. 
[9] S. R. Baquar, Medicinal and Poisonous Plants of Pakistan, Printas, Karachi, Pakistan, 1989.

[10] K. R. Kirtikar and B. M. Basu, Indian Medicinal Plants, Apura Krishna Bose Indian Press, Allahabad, India, 1918.

[11] H. M. Said, Hamdard Pharmacopoeia of Eastern Medicine, Hamdard National Foundation; Times Press; Sadar, Karachi, Pakistan, 1970.

[12] P. C. Braga, "Experimental models for the study of cough," in Cough, P. C. Braga and L. Allegra, Eds., pp. 55-70, Raven Press, New York, NY, USA, 1989.

[13] A. J. May and J. G. Widdicombe, "Depression of the cough reflex by pentobarbitone and some opium derivatives," British Journal of Pharmacology, vol. 9, pp. 335-340, 1954.

[14] J. C. Weidemier, "A screening method for antitussive compounds," Acta Physiologica et Pharmacologica Neerlandica, vol. 9, pp. 501-508, 1960

[15] M. G. Belvisi and D. J. Hele, "Animal models of cough," in Cough: Causes, Mechanisms and Therapy, H. Boushey, K. F. Chung, and J. G. Widdicombe, Eds., pp. 217-222, Blackwell Science, Oxford, UK, 2003.

[16] D. Lorke, "A new approach to practical acute toxicity testing," Archives of Toxicology, vol. 54, no. 4, pp. 275-287, 1983.

[17] L. L. Coughenour, J. R. McLean, and R. B. Parker, "A new device for the rapid measurement of impaired motor function in mice," Pharmacology Biochemistry and Behavior, vol. 6, no. 3, pp. 351353, 1977.

[18] J. Kamei, Y. Iwamoto, M. Misawa, and Y. Kasuya, "Effects of rimcazole, a specific antagonist of $\sigma$ sites, on the antitussive effects of non-narcotic antitussive drugs," European Journal of Pharmacology, vol. 242, no. 2, pp. 209-211, 1993.

[19] C. J. Kotzer, D. W. P. Hay, G. Dondio, G. Giardina, P. Petrillo, and D. C. Underwood, "The antitussive activity of $\delta$-opioid receptor stimulation in guinea pigs," Journal of Pharmacology and Experimental Therapeutics, vol. 292, no. 2, pp. 803-809, 2000.

[20] K. F. Chung and A. B. Chang, "Therapy for cough: active agents," Pulmonary Pharmacology and Therapeutics, vol. 15, no. 3, pp. 335-338, 2002.

[21] H. P. Rang, M. M. Dale, and J. M. Ritter, Pharmacology, Churchill Livingstone, 4th edition, 1999.

[22] J.-A. Karlsson, A.-S. Lanner, and C. G. A. Persson, "Airway opioid receptors mediate inhibition of cough and reflex bronchoconstriction in guinea pigs," Journal of Pharmacology and Experimental Therapeutics, vol. 252, no. 2, pp. 863-868, 1990.

[23] Z. R. Chen, R. J. Irvine, A. A. Somogyi, and F. Bochner, "Mu receptor binding of some commonly used opioids and their metabolites," Life Sciences, vol. 48, no. 22, pp. 2165-2171, 1991.

[24] V. E. Tyler, "Phytomedicines: back to the future," Journal of Natural Products, vol. 62, no. 11, pp. 1589-1592, 1999.

[25] P. V. Dicpinigaitis and J. B. Dobkin, "Antitussive effect of the GABA-agonist baclofen," Chest, vol. 111, no. 4, pp. 996-999, 1997.

[26] R. L. Mcleod, L. E. Parra, J. C. Mutter et al., "Nociceptin inhibits cough in the guinea-pig by activation of ORL1 receptors," British Journal of Pharmacology, vol. 132, no. 6, pp. 1175-1178, 2001.

[27] D. W. P. Hay, G. A. M. Giardina, D. E. Griswold et al., "Nonpeptide tachykinin receptor antagonists. III. SB 235375, a low central nervous system-penetrant, potent and selective neurokinin-3 receptor antagonist, inhibits citric acid-induced cough and airways hyper-reactivity in guinea pigs," Journal of Pharmacology and Experimental Therapeutics, vol. 300, no. 1, pp. 314-323, 2002.
[28] V. Schulz, R. Hänsel, and V. Tyler, Rational Phytotherapy, a Physicians' Guide to Herbal Medicine, Springer, Berlin, Germany, 4th edition, 2001.

[29] I. Ziment, "Herbal antitussives," Pulmonary Pharmacology and Therapeutics, vol. 15, no. 3, pp. 327-333, 2002.

[30] A. Amit, V. S. Saxena, N. Pratibha et al., "Mast cell stabilization, lipoxygenase inhibition, hyaluronidase inhibition, antihistaminic and antispasmodic activities of Aller-7, a novel botanical formulation for allergic rhinitis," Drugs Under Experimental and Clinical Research, vol. 29, no. 3, pp. 107-115, 2003.

[31] J. J. Adcock, "Peripheral opioid receptors and the cough reflex," Respiratory Medicine, vol. 85, pp. 43-46, 1991.

[32] C. A. Monteleone and A. R. Sherman, "Nutrition and asthma," Archives of Internal Medicine, vol. 157, no. 1, pp. 23-34, 1997.

[33] S. Eriksson, "Pulmonary emphysema and alphal-antitrypsin deficiency", Acta medica Scandinavica, vol. 175, pp. 197-205, 1964.

[34] L. Grievink, H. A. Smit, M. C. Ocké, P. Van 'T Veer, and D. Kromhout, "Dietary intake of antioxidant (pro)-vitamins, respiratory symptoms and pulmonary function the MORGEN study," Thorax, vol. 53, no. 3, pp. 166-171, 1998.

[35] E. Omenaas, Ø. Fluge, A. S. Buist, W. M. Vollmer, and A. Gulsvik, "Dietary vitamin C intake is inversely related to cough and wheeze in young smokers," Respiratory Medicine, vol. 97, no. 2, pp. 134-142, 2003.

[36] H.-Y. Cheng, T.-C. Lin, K.-H. Yu, C.-M. Yang, and C.-C. Lin, "Antioxidant and free radical scavenging activities of Terminalia chebula," Biological and Pharmaceutical Bulletin, vol. 26, no. 9, pp. 1331-1335, 2003

[37] M. K. Gautam, S. Goel, R. R. Ghatule, A. Singh, G. Nath, and R. K. Goel, "Curative effect of Terminalia chebula extract on acetic acid-induced experimental colitis: role of antioxidants, free radicals and acute inflammatorymarker," Inflammopharmacology. In press.

[38] G. H. Naik, K. I. Priyadarsini, D. B. Naik, R. Gangabhagirathi, and H. Mohan, "Studies on the aqueous extract of Terminalia chebula as a potent antioxidant and a probable radioprotector," Phytomedicine, vol. 11, no. 6, pp. 530-538, 2004.

[39] K. C. Huang, Pharmacology of Chinese Herbs, CRC Press, Boca Raton, Fla, USA, 2nd edition, 1999.

[40] J. A. Duke, Handbook of Medicinal Herbs, CRC Press, Boca Raton, Fla, USA, 2nd edition, 2002. 

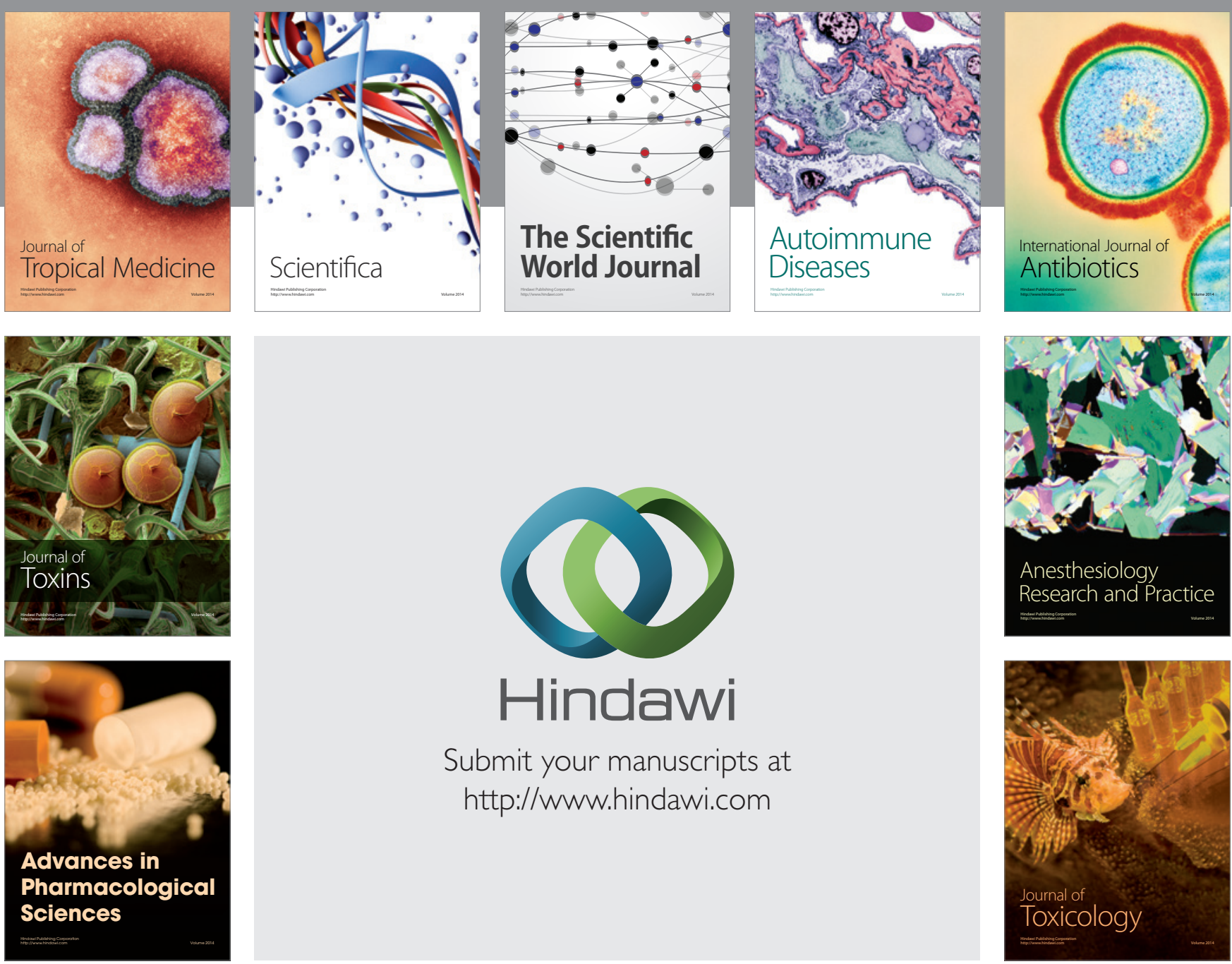

\section{Hindawi}

Submit your manuscripts at

http://www.hindawi.com
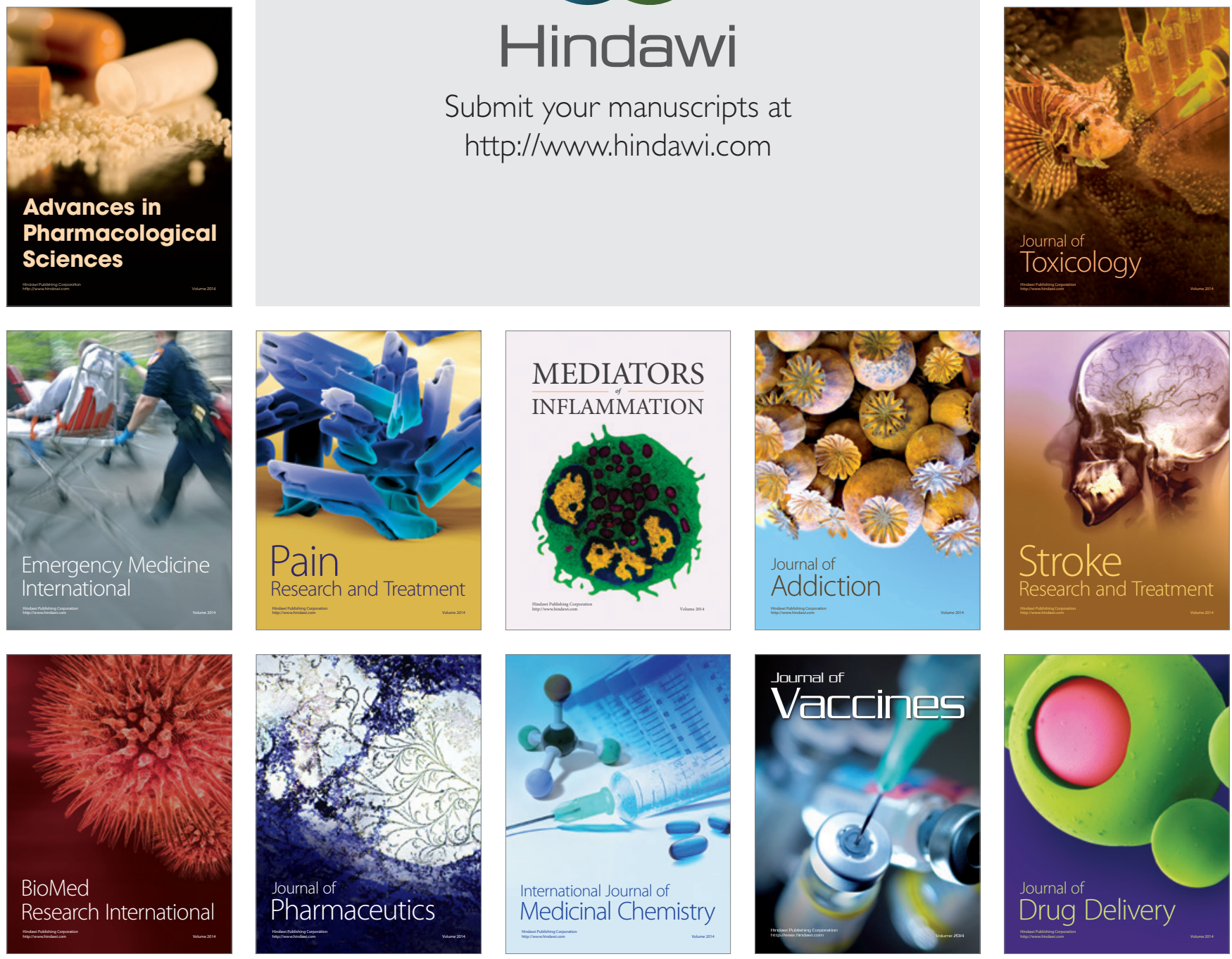